\title{
Preliminary data on the feeding habits of the endemic species Synodontis koensis Pellegrin, 1933 (Siluriformes, Mochokidae) in a West African River (Sassandra River Basin, Côte d'Ivoire)
}

\author{
S.S. Yao(1), K.A. Kouamé(1), N.I. Ouattara(1), G. Gooré Bi ${ }^{(1)}$, E.P. Kouamélan ${ }^{(1)}$
}

Received December 29, 2009 / Reçu le 29 décembre 2009

Revised April 11, 2010 / Révisé le 11 avril 2010

Accepted April 30, 2010 / Accepté le 30 avril 2010

\begin{abstract}
Key-words: In the implementation of programs for protection and management of Synodontis koensis, endemic species, feeding habit, Sassandra River, Côte d'Ivoire ichthyofauna, endemic species should have high priority in the conservation measures. Their fishery should be based on intimate knowledge of their ecology and biology.

Feeding habits of the endemic Mochokid Synodontis koensis were assessed in the Sassandra River (Côte d'Ivoire) in relation to the study zone, the specimen sex and size, and the season.

Of the 303 stomachs examined, 49 were empty (16\%). The fluctuation of the vacuity index indicated that $S$. koensis feeds more at night. The diet consisted mainly of plant detritus and chironomid larvae. The statistical analysis of the feeding according to the study zones, the sex of fish and the seasons does not show any significant difference between regimes, whereas significant ontogenic shifts in diet were observed.
\end{abstract}

\section{ABSTRACT}

\section{RÉSUMÉ}

Premières données sur les habitudes alimentaires de Synodontis koensis Pellegrin, 1933 (Siluriformes, Mochokidae), espèce endémique d'un bassin ouest-africain (fleuve Sassandra, Côte d'Ivoire)

Mots-clés: Synodontis koensis, espèce endémique, habitude alimentaire, fleuve Sassandra, Côte d'lvoire
Dans la mise en œuvre de programmes pour la protection et la gestion de l'ichtyofaune, les espèces endémiques doivent faire l'objet d'une attention particulière. Leur exploitation doit se faire sur la base d'une bonne connaissance de leurs écologie et biologie.

Les habitudes alimentaires de Synodontis koensis, espèce endémique du fleuve Sassandra (Côte d'Ivoire), ont été étudiées pour la première fois en fonction de la zone d'étude, du sexe et de la taille des spécimens et de la saison.

Sur 303 estomacs examinés, 49 étaient vides (16\%). La variation de l'indice de vacuité indique que $S$. koensis se nourrit surtout la nuit. Elle consomme principalement des débris végétaux et des larves de Chironomidae. Le régime alimentaire ne présente de variation statistiquement significative ni en fonction de la zone d'étude, du sexe et ni des saisons. À l'inverse, il est fonction de la taille des individus.

(1) Laboratoire d'Hydrobiologie, UFR Biosciences, Université de Cocody-Abidjan, 22 BP 582 Abidjan 22, Côte d'Ivoire, yaosilvain@yahoo.com 


\section{INTRODUCTION}

In Africa, river and lake basins are undoubtedly of vital importance in providing food security, employment, tradable products, income, and cultural and aesthetic values for millions of people (Béné, 2005; Emerton, 2005). Unfortunately, the last decades have witnessed increasing pressures on freshwater systems through introduced species, overexploitation, water pollution, hydropower and hydroelectric development, catchment deforestation, water diversions, and overall land use change (Chapman and Chapman, 2003). Like in the other rivers of Côte d'Ivoire (West Africa), the Sassandra river faces threats from agricultural and industrial pollution, and the current lack of adequate policing of the ecosystems in the north of the country because of civil war (Thieme et al., 2005; Kouamé et al., 2008). In addition, a second hydroelectric dam has been proposed for construction downstream on Sassandra River.

The extent of threats requires us to establish priorities and to set goals and targets for the protection of aquatic systems and their biodiversity. On this point, much attention must be paid to the conservation of endemic species and the management of their habitats. The Mochokidae (Teleostei, Siluriformes) is one of the African fish families which contain a high number of endemic species (Paugy and Roberts, 2003). Of these endemic mochokids, the species Synodontis koensis is only known from the Sassandra basin. This fish is commercially exploited in all regions where it occurs. The other representatives of the genus (S. bastiani, S. punctifer and $S$. schall) are more widely distributed in Côte d'lvoire. Although at present $S$. koenis is not classified as overexploited, nor endangered species, management measures should be taken before conservation status becomes critical. Investigations on life-history characteristics such as growth, diet, reproduction, etc., are needed for the species management and conservation programs (Dadzie, 2007; Leunda et al., 2007). Several studies have dealt with some species of the genus Synodontis. Nevertheless, the references about S. koensis concern only its systematic, distribution (Paugy and Roberts, 2003) and breeding period (Traoré, 1996). Thus, no information is available on its feeding habits.

The main objectives of the present work were to examine the feeding habits of the endemic species Synodontis koensis. Emphasis was placed on the assessment of space, sex, size, and season-related feeding habits.

\section{MATERIAL AND METHODS}

\section{> STUDY AREA}

The Sassandra River Basin flows through western Côte d'Ivoire to the Atlantic Ocean. It runs for approximately $840 \mathrm{~km}$ and drains $75000 \mathrm{~km}^{2}$ (Lemoalle, 1999). The lake Buyo, formed from the lower Sassandra impoundment in 1981, covers $920 \mathrm{~km}^{2}$ and provides electric power (Traoré, 1989). The present study was restricted to the lower course of the basin (Figure 1) because an armed conflict has prevented field work in northern Côte d'Ivoire since September 2002. The vegetation of the region is primarily tropical rainforest. Two dry and two wet seasons are recognized in the study area (Eldin, 1971). The long dry season (LD) extends from December to March and the second one (SD) from July to September. The long wet season (LW) occurs from April to June and the short one (SW) from October to November. The study area is divided into three zones: the main channel and two major tributaries, Lobo and Davo. The wide main river channel receives less shade from streamside forests than smaller tributaries which are shaded by overhanging canopy of riparian vegetation. The fluctuations in stream level and flow rate are determined by both intensity of precipitation and discharge from the Buyo dam. Synodontis koensis were collected at 11 stations of which 4 (stations Sa1-Sa4) are located on the main channel, 3 (Sa5-Sa7) on the Lobo tributary and 4 (Sa8-Sa11) on the Davo tributary (Figure 1). The stations were selected based on an easy accessibility by the road and a possibility for conducting a sampling program. 


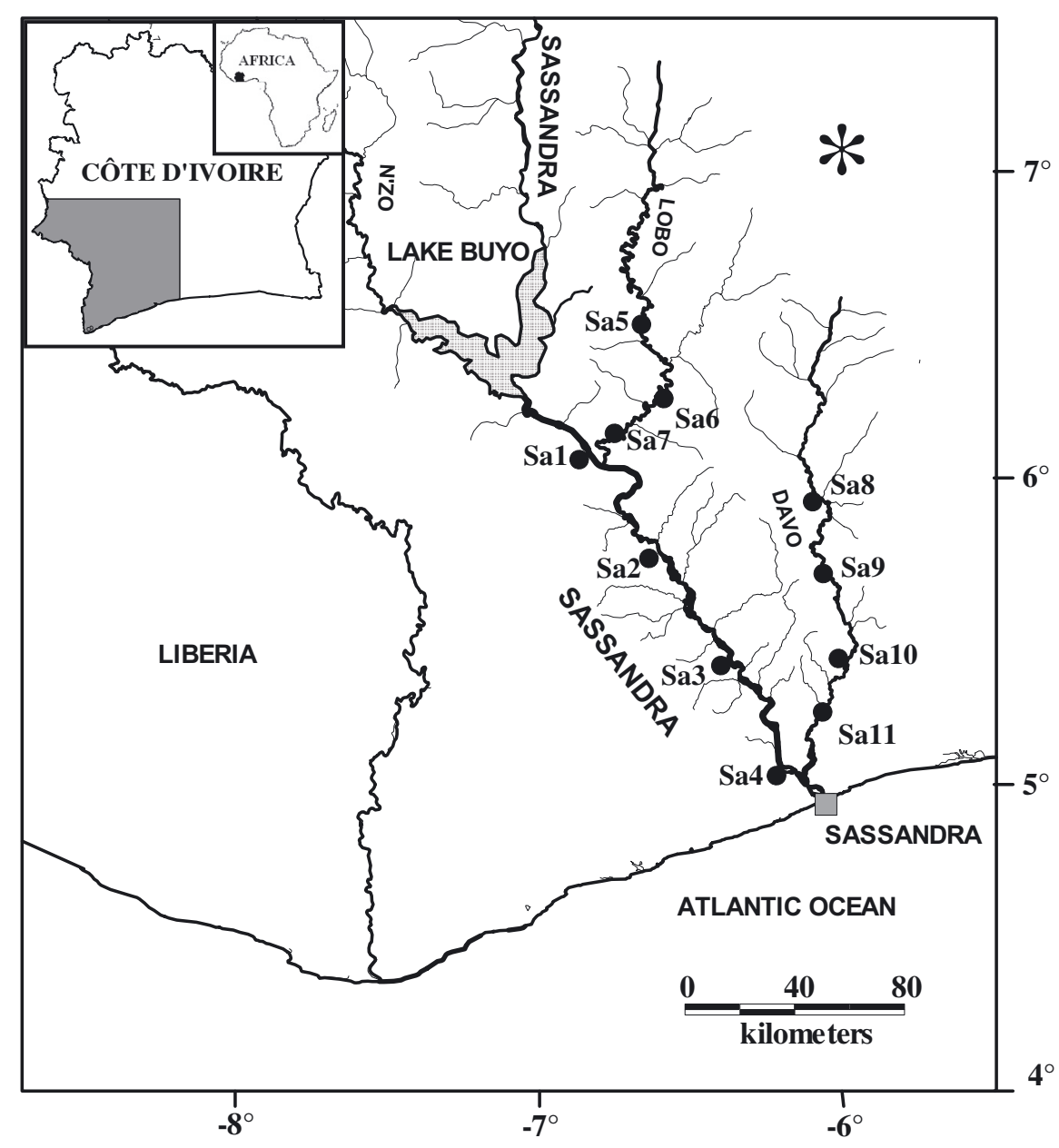

Figure 1

Positions of the sampling sites (Sa1-Sa11) on the Sassandra River Basin (Côte d'lvoire).

Figure 1

Situation des sites d'échantillonnage (Sa1-Sa11) sur le bassin de la rivière Sassandra (Côte d'Ivoire).

\section{> SAMPLING AND STOMACH CONTENTS ANALYSIS}

Each station was sampled four times: twice in the wet season (October-November 2004 and May-June 2005) and twice during the dry season (January-February 2005 and August-September 2005). Thirteen weighted gill-nets, $30 \mathrm{~m}$ in length, $2.5 \mathrm{~m}$ in height, and of $8,10,12,15,20,25,30,35,40,45,50,55$ and $60 \mathrm{~mm}$ stretched mesh size were employed to capture fish. Nets were set at 5 p.m. and fish were removed at 7 a.m and again at 12 a.m. In the field the fish caught were identified following Paugy and Roberts (2003), and standard length $(\mathrm{mm})$ and body weight $(\mathrm{g})$ were recorded for each specimen. Specimens were then dissected, their stomachs removed and preserved in 5\% formalin solution. Sex was determined by visual inspection of urinogenital papilla and gonads. In the laboratory, each stomach was slit open and its contents were placed in a Petri dish and the aggregates were dispersed with distilled water. Item number and wet weight to the nearest $0.01 \mathrm{~g}$ were recorded after removal of surface water by blotting on tissue paper. The preys were then identified to the lowest taxonomic level possible according to Durand and Lévêque (1980, 1981), Dejoux et al. (1981) and using a binocular microscope. 
Three indexes were calculated for qualitatively and quantitatively expressing the importance of the different preys in the diet. These were:

(1) Corrected occurrence percentage $\left(F_{C}\right)$ (Rosecchi and Nouaze, 1987):

$$
F_{\mathrm{C}}=\frac{F_{i}}{\sum F_{i}} \times 100 \text { with } F_{i}=\frac{n_{i}}{N_{\mathrm{T}}}
$$

where $F_{i}$ represents the frequency of prey $i, n_{i}$ the number of stomachs including prey $i$ and $N_{\mathrm{T}}$ the total number of non-empty stomachs examined.

(2) Weight percentage (W) (Hyslop, 1980):

$$
W=\frac{W_{\mathrm{i}}}{W_{\mathrm{T}}} \times 100
$$

where $W_{i}$ represents the total weight of prey $i$ and $W_{\mathrm{T}}$ the total weight of all preys.

(3) The index of preponderance (Ip) (Natarajan and Jhingran, 1961), combining the occurrence

$\left(F_{\mathrm{C}}\right)$ and weight $(W)$ percentages, was used to assess the relative importance of each type of prey:

$$
\text { Ip }=\frac{F_{\mathrm{C}} \times W}{\sum\left(F_{\mathrm{C}} \times W\right)} \times 100 .
$$

The index of preponderance $(/ \mathrm{p})$ varies from 0 to $100 \%$. Different prey taxa were arranged according to the classification scale of Simenstad (1979): first, the items are arranged by decreasing index value; cumulative Ip was then calculated. The items for which cumulative Ip was equal or superior to $50 \%$ were considered as preferential ones. The items for which the index value added to that of the preferential, reaches at least $75 \%$, were regarded as secondary prey. All the other items represent incidental preys.

To assess for possible changes in diet with respect to fish size, different size classes were defined following Sturge's rule (Scherrer, 1984):

- Number of classes $=1+\left(3.3 \log _{10} N\right)$, where $N=$ total number of specimens examined;

- Interval of classes $=\frac{S L_{\max }-S L_{\min }}{\text { total of classes }}$, where $S L=$ standard length.

The vacuity index (VI) was calculated in order to evaluate feeding intensity (Hureau, 1970):

$$
V I=\frac{\text { number of empty stomachs }}{\text { total of stomachs }} \times 100 \text {. }
$$

Effects of space, length class, season and sex on diet were tested by Spearman rank-order analysis (Snedecor and Cochran, 1989). The variation in vacuity index was tested by a chisquare test over a contingency table of number of empty stomachs (Sokal and Rohlf, 1981). These analyses were performed with the software Statistica version 7.1 and $\mathrm{R}$, respectively.

\section{RESULTS}

\section{> FEEDING INTENSITY}

Of the 303 stomachs of $S$. koensis examined (148 stomachs for the main channel, 86 for the Lobo tributary and 69 for the Davo tributary), 49 were empty, indicating a vacuity index of $16 \%$. This index (14\% in the main channel, $15 \%$ in the Lobo tributary and $22 \%$ in the Davo tributary) didn't differ significantly among the study areas $\left(\chi^{2}=2.077, p>0.05\right)$ (Table I). Similar results were found among the sexes (15\% in males, $17 \%$ in females; $\chi^{2}=0.116$, $p>0.05)$, the seasons (19\% in SW, $16 \%$ in LD, $21 \%$ in LW, $13 \%$ in SD; $\chi^{2}=3.730, p>0.05$ ) and the size classes (18\% in size class $50-60 \mathrm{~mm}, 15 \%$ in size class $60-140 \mathrm{~mm} ; \chi^{2}=0.047$, $p>0.05$ ). Conversely, in each study area (Figure 2), the fluctuation of the vacuity index showed significant daily differences in feeding intensity characterized by a higher proportion of empty stomachs recorded during the day than during the night $\left(\chi^{2}=42.599, p<0.05\right)$. The maximum vacuity index observed during the night was of $13 \%$ (in Davo tributary) and the minimum during the day was of $32 \%$ (in Lobo tributary). 


\section{Table I}

Number of specimens of Synodontis koensis caught in Sassandra River basin (Côte d'Ivoire) and variations of the vacuity index according to study areas.

Tableau I

Nombre d'individus de Synodontis koensis capturés dans le bassin de la rivière Sassandra (Côte d'Ivoire) et variations de l'indice de vacuité selon les sites d'étude.

\begin{tabular}{|l|c|c|c|c|}
\hline Study area & Specimens examined & Full stomachs & Empty stomachs & Vacuity index (\%) \\
\hline Main channel & 148 & 127 & 21 & 14.19 \\
\hline Lobo tributary & 86 & 73 & 13 & 15.12 \\
\hline Davo tributary & 69 & 54 & 15 & 21.74 \\
\hline Total & 303 & 254 & 49 & 16.17 \\
\hline
\end{tabular}

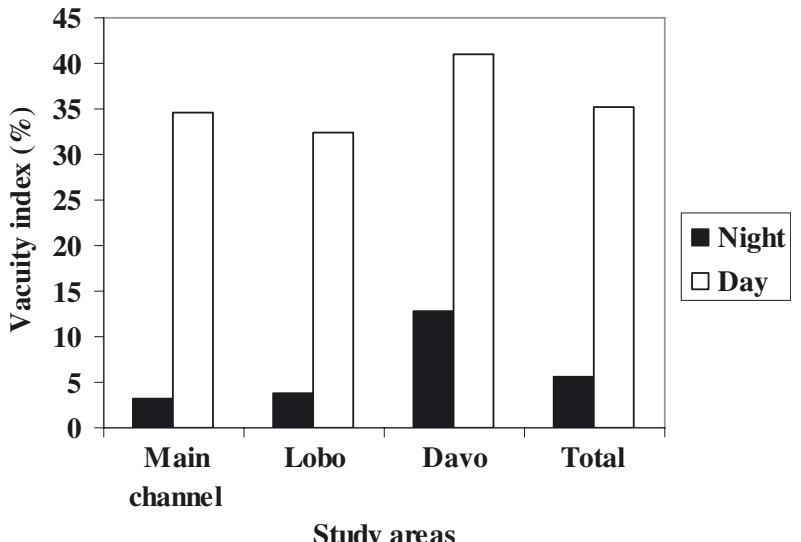

\section{Figure 2}

Diel variation in vacuity index for Synodontis koensis from Sassandra River Basin (Côte d'Ivoire).

Figure 2

Variations journalières de l'alimentation de Synodontis koensis de la rivière Sassandra (Côte d'Ivoire).

\section{> GENERAL DIET COMPOSITION}

The trophic spectrum of $S$. koensis $(n=254)$ shows that 14 items, excluding sand grains and mud, constituted its diet (Table II). They were assigned to five categories: (1) insects ( $n=8$; chironomid larvae, Ceratopogon sp., Chaoborus sp., Baetidae, Povilla sp., Ecnomus sp., Hydropsychidae and Formicidae), (2) crustacea ( $n=3$; ostracoda, cladocera and copepoda), (3) molluscs ( $n=1$; bivalves), (4) macrophytes ( $n=1$; plant detritus) and (5) other prey ( $n=1$; fish scales). Plant detritus (fragments of bark and leaves of macrophytes, peel, pulp and seeds of fruits) occurred most frequently $\left(F_{\mathrm{C}}=42.1 \%\right)$, followed by chironomids $\left(F_{C}=25.3 \%\right)$. Lowest frequencies were showed by the crustaceans cladocera and copepoda with respectively $F_{\mathrm{C}}=1.1 \%$. In terms of weight, plant detritus constituted the principal food items, with $W=70.3 \%$, followed by chironomids $(W=18.2 \%)$. In relation to the feeding index (Ip), the most important food sources were plant detritus $(/ p=74.4 \%)$. The diet was supplemented with chironomids $(/ p=21.9 \%)$. The other prey items were quite negligible and together represented less than $4 \%$ Ip of the diet. According to the classification of Simenstad (1979), plant detritus were classified in the principal prey category, while chironomids as secondary prey. All the other taxa represent accessory items.

\section{> SPATIAL VARIATIONS OF DIET}

Figure 3 synthesizes $/ \mathrm{p} \%$ for major prey categories in S. koensis from the three study zones. Plant detritus were the most important ingested prey in the main channel, and the Lobo 
Table II

Diet composition of Synodontis koensis ( $n=254 ; 50-140 \mathrm{~mm}$ standard length) from the Sassandra River basin (Côte d'Ivoire).

$W=$ weight percentage; $F_{\mathrm{C}}=$ corrected occurrence percentage; $/ \mathrm{p}=$ index of preponderance.

\section{Tableau II}

Composition du régime alimentaire de Synodontis koensis $(n=254 ; 50-140 \mathrm{~mm}$ longueur standard) du bassin de la rivière Sassandra (Côte d'Ivoire).

$W=$ pourcentage pondéral $; F_{C}=$ pourcentage d'occurrence corrigé $; / p=$ indice de prépondérance.

\begin{tabular}{|l|c|c|c|}
\hline Prey taxa & $W(\%)$ & $F_{\mathrm{C}}(\%)$ & $/ \mathrm{p}(\%)$ \\
\hline INSECTS \\
\hline Diptera \\
\hline Chironomid larvae & 18.24 & 25.26 & 21.93 \\
\hline Ceratopogon sp. & 0.16 & 1.35 & 0.01 \\
\hline Chaoborus sp. & 1.03 & 1.17 & 0.06 \\
\hline Ephemeroptera \\
\hline Baetidae \\
\hline Povilla sp. & 0.17 & 0.26 & 0.002 \\
\hline Trichoptera & 0.25 & 0.26 & 0.003 \\
\hline Ecnomus sp. & 0.71 & 1.26 & 0.04 \\
\hline Hydropsychidae & 1.56 & 1.34 & 0.10 \\
\hline Hymenoptera & 0.37 & 1.17 & 0.02 \\
\hline Formicidae & 0.25 & 3.26 & 0.04 \\
\hline CRUSTACEA & 0.05 & 1.09 & 0.002 \\
\hline Ostracoda & 0.05 & 1.09 & 0.002 \\
\hline Cladocera \\
\hline Copepoda \\
\hline MOLLUSCS & 2.20 & 9.78 & 1.02 \\
\hline Bivalves \\
\hline MACROPHYTES \\
\hline Plant detritus & 70.25 & 42.11 & 74.39 \\
\hline OTHER PREY & 4.71 & 10.61 & 2.38 \\
\hline Fish scales & 22.49 & 32.07 & 22.17 \\
\hline TOTAL & 0.35 & 5.43 & 0.04 \\
\hline INSECTS & 2.20 & 9.78 & 1.02 \\
\hline CRUSTACEA & 70.25 & 42.11 & 74.39 \\
\hline MOLLUSCS & 4.71 & 10.61 & 2.38 \\
\hline MACROPHYTES \\
\hline OTHER PREY & \multicolumn{5}{|l|}{} \\
\hline
\end{tabular}

and Davo tributaries, constituting $82.30 \%, 62.26 \%$ and $77.77 \%$ of the total $/ \mathrm{p}$, respectively. These food items were followed by chironomids ( $/ \mathrm{p}=15.56 \%, 32.14 \%$ and $19.75 \%$, respectively), while other prey groups were comparatively lower and of less importance. The Spearman tests confirmed that diets in the three areas were similar (Table III).

\section{> DIET VARIATIONS ACCORDING TO SEX}

Of the 254 specimens examined, 103 were males (52 to $137 \mathrm{~mm} \mathrm{SL)} \mathrm{and} 151$ females (50 to $140 \mathrm{~mm} \mathrm{SL}$ ). Plant detritus ( $/ \mathrm{p}=67.4 \%$ in males and $74.3 \%$ in females) and chironomids ( $/ \mathrm{p}=24.2 \%$ in males and $21.0 \%$ in females) were the dominant food for both sexes (Figure 4). The Spearman test proved that diets of males and females were significantly correlated $(p=0.0036 ; R=0.70)$. 


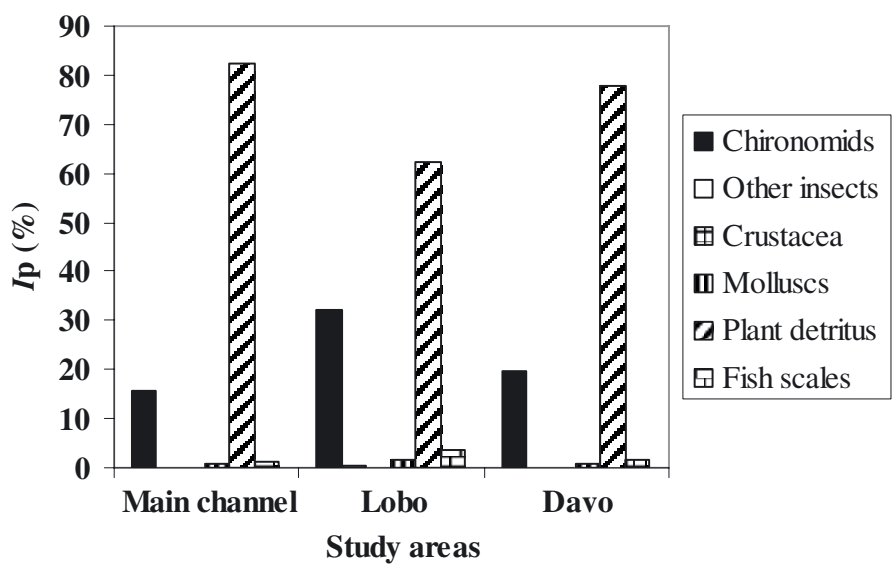

Figure 3

Spatial variations in diet of Synodontis koensis in Sassandra River Basin (Côte d'Ivoire).

Figure 3

Variations spatiales de l'alimentation de Synodontis koensis de la rivière Sassandra (Côte d'Ivoire).

\section{Table III}

Results of Spearman rank order correlation analysis for testing differences in food composition between study areas, size classes (SC) and seasonal samples of Synodontis koensis from the Sassandra River basin (Côte d'Ivoire).

SC1 = group $1=50 \leq S L \leq 60 \mathrm{~mm} ; \mathrm{SC2}=60<\mathrm{SL} \leq 70 \mathrm{~mm} ; \mathrm{SC} 3=70<\mathrm{SL} \leq 80 \mathrm{~mm} ; \mathrm{SC4}=80<$ $S L \leq 90 \mathrm{~mm} ; \mathrm{SC5}=90<S L \leq 140 \mathrm{~mm} ;$ group $2=S C 2+$ SC3 + SC4 + SC5; $D=$ dry season; $W=w e t$ season; * $=$ correlation is significant at $p<0.05$.

\section{Tableau III}

Résultats de l'analyse de corrélation de rangs de Spearman testant les différences de composition alimentaire entre les sites d'étude, classes de taille (SC) et saison d'échantillonnage de Synodontis koensis du bassin de la rivière Sassandra (Côte d'Ivoire).

$\mathrm{SC} 1=$ groupe $1=50 \leq \mathrm{SL} \leq 60 \mathrm{~mm} ; \mathrm{SC} 2=60<\mathrm{SL} \leq 70 \mathrm{~mm} ; \mathrm{SC} 3=70<\mathrm{SL} \leq 80 \mathrm{~mm}$; SC4 = $80<\mathrm{SL} \leq 90 \mathrm{~mm} ; \mathrm{SC} 5=90<\mathrm{SL} \leq 140 \mathrm{~mm}$; group 2 = SC2 + SC3 + SC4 + SC5; D = saison sèche; $W=$ saison humide; * $=$ corrélation significative à $p<0.05$.

\begin{tabular}{|c|c|c|c|}
\hline Source of variation & $\begin{array}{c}\text { Spearman coefficient } \\
\text { of correlation } \mathrm{R}\end{array}$ & $t(N-2)$ & $\overline{p \text {-level }}$ \\
\hline \multicolumn{4}{|l|}{ Study area } \\
\hline Main channel - Lobo & 0.73 & 3.71 & $0.003^{\star}$ \\
\hline Main channel - Davo & 0.83 & 5.08 & $0.0003^{\star}$ \\
\hline Lobo - Davo & 0.88 & 6.42 & $0.00003^{*}$ \\
\hline \multicolumn{4}{|l|}{ Size } \\
\hline SC1 - SC2 & 0.07 & 0.26 & 0.80 \\
\hline SC1 - SC3 & 0.14 & 0.51 & 0.62 \\
\hline SC1 - SC4 & 0.02 & 0.08 & 0.94 \\
\hline SC1 - SC5 & -0.02 & -0.06 & 0.95 \\
\hline SC2 - SC3 & 0.84 & 5.60 & $0.00009^{*}$ \\
\hline SC2 - SC4 & 0.58 & 2.58 & $0.02^{*}$ \\
\hline SC2 - SC5 & 0.66 & 3.13 & $0.008^{*}$ \\
\hline SC3 - SC4 & 0.78 & 4.43 & $0.0007^{*}$ \\
\hline SC3 - SC5 & 0.61 & 2.80 & $0.01^{*}$ \\
\hline SC4 - SC5 & 0.72 & 3.77 & $0.002^{*}$ \\
\hline \multicolumn{4}{|l|}{ Season } \\
\hline Group 1 (D) - Group 1 (W) & 0.82 & 3.15 & $0.03^{*}$ \\
\hline Group 2 (D) - Group 2 (W) & 0.62 & 2.50 & $0.03^{\star}$ \\
\hline
\end{tabular}




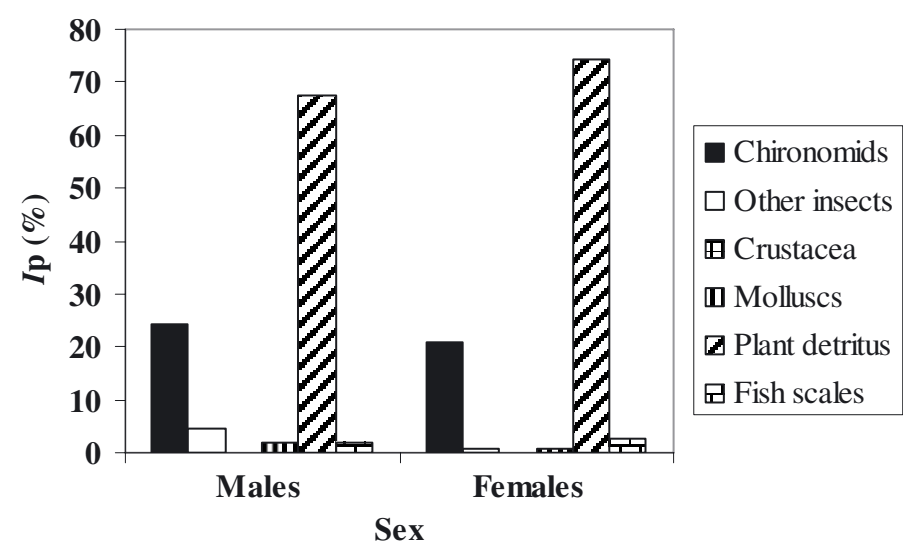

\section{Figure 4}

Diet of males $(n=103)$ and females $(n=151)$ of Synodontis koensis within the Sassandra River basin (Côte d'lvoire).

\section{Figure 4}

Alimentation des mâles $(n=103)$ et des femelles $(n=151)$ de Synodontis koensis de la rivière Sassandra (Côte d'Ivoire).

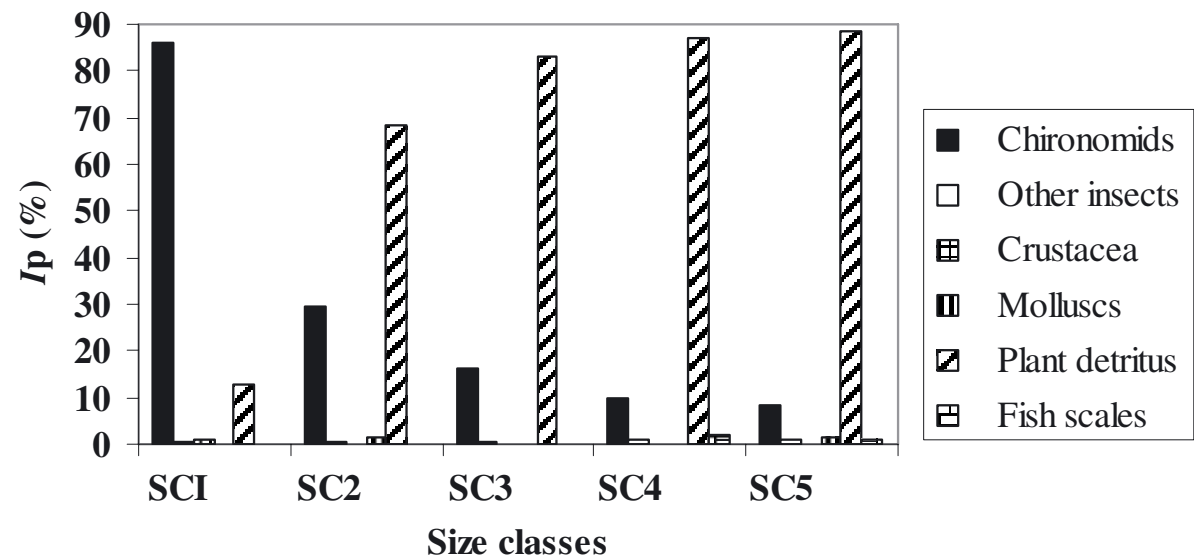

\section{Figure 5}

Composition of Synodontis koensis diet among size classes (SC) based on the \% Ip values of main prey categories. SC1 $(n=81)=50 \mathrm{~mm} \leq S L \leq 60 \mathrm{~mm}$; SC2 $(n=63)=60 \mathrm{~mm}<S L \leq 70 \mathrm{~mm}$; SC3 $(n=45)=$ $70 \mathrm{~mm}<\mathrm{SL} \leq 80 \mathrm{~mm} ; \mathrm{SC} 4(n=34)=80 \mathrm{~mm}<\mathrm{SL} \leq 90 \mathrm{~mm} ; \mathrm{SC5}(\mathrm{n}=31)=90 \mathrm{~mm}<\mathrm{SL}$.

\section{Figure 5}

Composition du régime alimentaire de Synodontis koensis selon les classes de taille (SC) basée sur les valeurs \%/p des principales catégories de proie.

SC1 $(n=81)=50 \mathrm{~mm} \leq \mathrm{SL} \leq 60 \mathrm{~mm} ; \mathrm{SC} 2(n=63)=60 \mathrm{~mm}<\mathrm{SL} \leq 70 \mathrm{~mm} ; \operatorname{SC} 3(n=$ $45)=70 \mathrm{~mm}<\mathrm{SL} \leq 80 \mathrm{~mm} ; \mathrm{SC} 4(n=34)=80 \mathrm{~mm}<\mathrm{SL} \leq 90 \mathrm{~mm} ; \mathrm{SC} 5(n=31)=90 \mathrm{~mm}<\mathrm{SL}$.

\section{> DIET VARIATIONS ACCORDING TO SIZE}

Size of specimens of Synodontis koensis ranged from 50 to $140 \mathrm{~mm} \mathrm{SL}$, and nine class intervals were obtained according to Sturge's rule (Scherrer, 1984). Due to limited amount of samples from some of them $(n<30)$, the data were finally grouped into five size classes (Figure 5). Those size classes differed in terms of diet, with chironomids (/p $=85.8 \%$ ) relatively more important for the specimens from size class SC1, while plant detritus were more dominant $(/ p>60 \%)$ in the diet of larger fish. Taken all round, the $/ p$ of plant detritus increased 


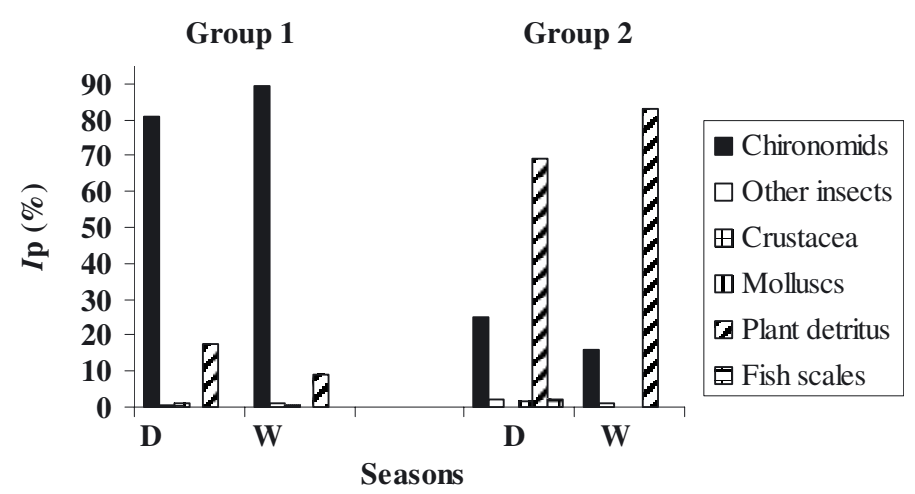

\section{Figure 6}

Seasonal composition of the feeding of Synodontis koensis based on the \%/p values of main prey categories.

Group $1(n=81)=50 \mathrm{~mm} \leq S L \leq 60 \mathrm{~mm}$; group $2(n=173)=60 \mathrm{~mm}<S L \leq 140 \mathrm{~mm} ; D=$ dry season; $W=$ wet season

\section{Figure 6}

Composition saisonnière du régime alimentaire de Synodontis koensis basée sur les valeurs \%/p des principales catégories de proie.

Groupe $1(n=81)=50 \mathrm{~mm} \leq \mathrm{SL} \leq 60 \mathrm{~mm}$; groupe $2(n=173)=60 \mathrm{~mm}<\mathrm{SL} \leq 140 \mathrm{~mm} ; \mathrm{D}=$ saison sèche; $\mathrm{W}$ = saison humide.

with S. koensis size whereas the Ip of chironomids decreased. The Spearman test revealed significant similarities between the diets of size classes SC2 to SC5 (Table III). On the other hand, the diets of these classes and that of the class SC1 weren't significantly correlated.

\section{> DIET VARIATIONS ACCORDING TO SEASON}

As there were no significant changes in the spectrum of food items consumed with size of fish, the data for the size classes SC2 to SC5 were pooled in the group 2 (60 $<\mathrm{SL} \leq$ $140 \mathrm{~mm} ; n=173$ ) for analysis of seasonal variation in diet. The results are presented in Figure 6 . In the group $1(50 \leq \mathrm{SL} \leq 60 \mathrm{~mm} ; n=81$ ), the prey types identified showed the dominance of chironomids in the dry season as well as in the rainy one $(/ \mathrm{p}=80.9 \%$ and $89.2 \%$ respectively). For the group 2 , in the dry season, plant detritus and chironomids were the most important ingested preys, constituting $69.18 \%$ and $24.9 \%$ of the total $/ p$, while other prey groups were comparatively lower and of less importance. A similar pattern was observed in the wet season, but with larger quantities for plant detritus (82.8\%) and smaller contribution for chironomids (16.0\%). The Spearman rank correlation coefficients attested that the seasonal variations in diet composition were significantly similar for both groups (Table III).

\section{DISCUSSION}

Feeding studies based on stomach contents are conditioned and influenced by a number of factors, including the stomachs repletion and the degree of digestion of the prey items. The high number of stomachs containing food (84\%) found in the diet of Synodontis koensis could be related to both its daily feeding cycle and the fish sampling period. Indeed, in the present study, the vacuity index showed markedly lower values during the night, suggesting that $S$. koensis is a nocturnal in feeding habits. This trend has been also evidenced for Synodontis schall (Lock, 1982; Idodo-Umeh, 2005) and S. membranaceus (Owolabi, 2008). On the other hand, Meye et al. (2008) reported that $S$. ocellifer fed mostly at night. 
Synodontis koensis consumed mostly plant detritus and chironomid larvae found in the substratum. Similar diets were described previously in Côte d'Ivoire for S. comoensis from the Comoé River basin (Koné et al., 2008), S. bastiani (Diomandé et al., 2001) and S. schall (Diomandé, 2001) from the River Bia. Taken together, the results of these studies bring out the preponderance of chironomid larvae in the diets of some fishes. The large proportion of this item in the diets is a reflection of its abundance in the streams as stated by Dejoux et al. (1981). The Synodontis and several other catfishes preference for benthic organisms could be largely attributed to the ventral location and the structure of their mouth (Lalèyè et al., 2006). Synodontis koensis can be classified as an omnivorous since it combined plant materials $\left(42.1 \% F_{C} ; 74.4 \% / p\right)$ with invertebrates $\left(47.3 \% F_{C} ; 23.2 \% / p\right)$ in its food.

Most stomachs (72\% of full stomachs) contained significant amounts of sand and mud (48.4\% of the total stomach contents weight) which provides evidence that $S$. koensis fed on the substrate. Many other Synodontis species such as S. bastiani, S. schall and S. comoensis (Yao, 2006) were also found to ingest mud and sand. According to Vilella et al. (2002), the possible reasons for the ingestion of sand are: (1) the consumption of biofilm associated to the sediment; (2) the importance of the sand in mechanic digestion of plant items or hard parts of some food items (insects, crustaceans, etc.); or (3) a low efficiency of the gill rakers in avoiding the ingestion of sand with the actual food items.

The consumption of fish scales by Synodontis species has been observed by several authors (e.g. Lauzanne, 1988; Ofori-Danson, 1992). However, whether or not the Synodontis, especially $S$. koensis actively searches for scales or ingest them at random is a question that remains to be investigated. Nevertheless, the frequent presence of this item suggests it might be important in the diet of Synodontis. Thus, fish scales may be a source of calcium for the fish feeding on them (Vilella et al., 2002).

Feeding habits differed among size classes principally, in the increasing importance of plant detritus, and decreasing importance of chironomids in the diet with increased fish size. The increasing size and variety of food resources used as specimens grow is a common pattern among fishes (Paugy and Lévêque, 2006). In the present study, these ontogenetic shifts in food preferences could be explained by morphological and physiological ontogenetic shifts, and by energetic requirements for growth. Indeed, larger fish have different feeding requirements than smaller ones and focus on more rewarding prey (larger and heavier), since length increase is related to mouth width and gape increase. Ontogenetic shifts in the diet also can be associated to a possible ecological strategy to reduce intraspecific competition for food in the population (Pallaoro et al., 2006; Jardas et al., 2007).

No significant spatial, nor seasonal difference in the diet of $S$. koensis was noticed. This result could be explained by availability of the preferential prey items (plant detritus and chironomids) within all the study areas and throughout the year.

In summary, the diet of $S$. koensis is similar to other Synodontis in view of large proportions of benthic items. Individuals smaller than $61 \mathrm{~mm}$ SL show carnivorous habits, feeding preferably on chironomid larvae, while larger individuals exhibit detritivorous diet with plant detritus being the major items.

\section{ACKNOWLEDGEMENTS}

This work forms part of a Vlaamse Interuniversitaire Raad project entitled "Characterization, utilization and conservation of freshwater fish biodiversity in Côte d'Ivoire", and was financed by the Belgian Directorate General for International Cooperation. We are indebted to the staff of the Hydrobiology Laboratory of Cocody-Abidjan University for fieldwork assistance. Also thanks to anonymous reviewers for their critical reading of the manuscript. 


\section{REFERENCES}

Béné C., 2005. Contribution of inland fisheries to rural livelihoods and food security in Africa: an overview. In: Thieme M.L., Abell R., Stiassny M.L.J., Skelton P., Lehner B., Teugels G.G., Dinerstein E., Kamdem Toham A., Burgess N. and Olson D. (eds.), Freshwater ecoregions of Africa and Madagascar: a conservation assessment, Island Press, Washington DC, 6-11.

Chapman L.J. and Chapman C.A., 2003. Fishes of the African rainforests: emerging and potential threats to a little-known fauna. In: Crisman T.L., Chapman L.J., Chapman C.A. and Kaufman L.S. (eds.), Conservation, ecology and management of African freshwaters, University of Florida Press, Gainesville, 176-209.

Dadzie S., 2007. Food and feeding habits of the black pomfret, Parastromateus niger (Carangidae) in the Kuwaiti waters of the Arabian Gulf. Cybium, 31, 1, 77-84.

Dejoux C., Elouard J.M., Forge P. and Maslin J.L., 1981. Catalogue iconographique des insectes aquatiques de Côte d'Ivoire. Rapport ORSTOM, 42, 1-178.

Diomandé D., 2001. Macrofaune benthique et stratégies alimentaires de Synodontis bastiani Daget, 1948 et S. schall (Bloch and Schneider, 1801) (Bassins de la Bia et Agnébi ; Côte d'Ivoire). Thèse de Doctorat, Université d'Abobo-Adjamé, Côte d'Ivoire, 260 p.

Diomandé D., Gourène G. and Tito De Morais L., 2001. Stratégies alimentaires de Synodontis bastiani (Siluriformes: Mochokidae) dans le complexe fluvio-lacustre de la Bia, Côte d'Ivoire. Cybium, 25, 1, 7-21.

Durand J.R. and Lévêque C., 1980. Flore et faune aquatiques de l'Afrique sahelo-soudanienne, Tome I, ORSTOM, Paris, 1-390.

Durand J.R. and Lévêque C., 1981. Flore et faune aquatiques de l'Afrique sahelo-soudanienne, Tome II, ORSTOM, Paris, 391-873.

Eldin M., 1971. Le climat. In: Avenard J.M., Eldin M., Girard G., Sircoulon J., Touchebeuf P., Guillaumet J.L., Adjanohoun E. and Perraud A. (eds.), Le milieu naturel en Côte d'Ivoire, ORSTOM, Paris, 77-108.

Emerton L., 2005. The economic value of Africa's wetlands. In: Thieme M.L., Abell R., Stiassny M.L.J., Skelton P., Lehner B., Teugels G.G., Dinerstein E., Kamdem Toham A., Burgess N. and Olson D. (eds.), Freshwater ecoregions of Africa and Madagascar: a conservation assessment, Island Press, Washington DC, 11-18.

Hureau J.-C., 1970. Biologie comparée de quelques poissons antarctiques (Nototheniidae). Thèse d’État, Bull. Inst. Océanogr. Monaco, Université de Paris, 224 p.

Hyslop E.J., 1980. Stomach contents analysis, a review of methods and their application. J. Fish Biol., 17, 411-429.

Idodo-Umeh G., 2005. The feeding ecology of Mochokid species in River Ase, Niger Delta, Nigeria. Trop. Freshwat. Biol., 14, 71-93.

Jardas I., Šantić M., Nerlović V. and Pallaoro A., 2007. Diet of the smooth-hound, Mustelus mustelus (Chondrichthyes: Triakidae), in the eastern Adriatic Sea. Cybium, 31, 4, 459-464.

Koné T., Kouamélan E.P., Yao S.S., N'Douba V. and Ollevier F., 2008. First results of a study of the feeding habits of Synodontis comoensis (Siluriformes: Mochokidae) in a West African river (Comoé River, Comoé National Park, Côte d'Ivoire). Aquat. Ecol., 42, 35-42.

Kouamé K.A., Yao S.S., Gooré Bi G., Kouamélan E.P., N’Douba V. and Kouassi N.J., 2008. Influential environmental gradients and patterns of fish assemblages in a West African basin. Hydrobiologia, $603,159-169$

Lalèyè P., Chikou A., Gnohossou P., Vandewalle P., Philippart J.C. and Teugels G.G., 2006. Studies on the biology of two species of catfish Synodontis schall and Synodontis nigrita (Ostariophysi: Mochokidae) from the Ouémé River, Bénin. Belg. J. Zool., 136, 193-201.

Lauzanne L., 1988. Les habitudes alimentaires des poissons d'eau douce africains. In: Lévêque C., Bruton M.N., Ssentongo G.W. (eds.), Biologie et écologie des poissons d'eau douce africains, ORSTOM, Paris, 221-242.

Lemoalle J., 1999. La diversité des milieux aquatiques. In: Lévêque C. and Paugy D. (eds.), Les poissons des eaux continentales africaines : diversité, écologie, utilisation par l'homme, Éditions de l'IRD, Paris, 11-30.

Leunda P.M., Miranda R. and Oscoz J., 2007. Occurrence and conservation of the threatened endemic cobitid, Cobitis calderoni, in the Erro River (Ebro Basin, Spain). Cybium, 31, 1, 13-18. 
Lock J.M., 1982. The biology of Siluriform fishes in Turkana. In: Hopson A.J. (ed.), Lake Turkana A report of the findings of the Lake Turkana - Project 1972-1975, Overseas Development Admnistration, London, 1021-1281.

Meye J.A., Omoruwou P.E. and Mayor E.D., 2008. Food and feeding habits of Syndontis ocellifer (Boulenger, 1900) from River Adofi, southern Nigeria. Trop. Freshwat. Biol., 17, 1, 1-12.

Natarajan A.V. and Jhingran A.G., 1961. Index of preponderance - a method of grading the food elements in the stomach analysis of fishes. Indian J. Fish., 8, 54-59.

Ofori-Danson P.K., 1992. Ecology of some species of catfish Synodontis (Pisces: Mochocidae) in the Kpong Headpond in Ghana. Environ. Biol. Fishes, 35, 49-61.

Owolabi O.D., 2008. The dietary habits of the upside-down catfish, Synodontis membranaceus (Osteichthyes: Mochokidae) in Jebba lake, Nigeria. Rev. Biol. Trop., 56, 2, 931-936.

Pallaoro A., Šantiæ M. and Jardas I., 2006. Feeding habits of the common two-banded sea bream, Diplodus vulgaris (Sparidae), in the eastern Adriatic Sea. Cybium, 30, 1, 19-25.

Paugy D. and Lévêque C. and 2006. Régimes alimentaires et réseaux trophiques. In: Lévêque C. and Paugy D. (eds.), Les poissons des eaux continentales africaines : diversité, écologie, utilisation par I'homme, Éditions de l'IRD, Paris, 191-215.

Paugy D. and Roberts T., 2003. Mochokidae. In: Paugy D., Lévêque C. and Teugels G.G. (eds.), Poissons d'eaux douces et saumâtres de l'Afrique de l'Ouest, Tome 2, MRAC, MNHN and IRD, Paris, 195-268.

Rosecchi E. and Nouaze Y., 1987. Comparaison de cinq indices utilisés dans l'analyse des contenus stomacaux. Rev. Trav. Inst. Pêches Marit., 49, 111-123.

Scherrer B., 1984. Présentation des données. In: Morin G. (ed.), Biostatistique, Boucherville, Canada, 103-126.

Simenstad C.A., 1979. Fish food habits analysis. In: National Oceanic and Atmospheric Administration/Environmental Research Laboratories (ed.), Environmental Assessment of the Alaskan Shelf - Principal Investigation Report and Assessment of Alaskan Continental Shelf, Boulder, Colorado, 441-450.

Snedecor G.W. and Cochran W.G., 1989. Statistical Methods, University Press/AMES, lowa State, $503 \mathrm{p}$.

Sokal R.R. and Rohlf F.J., 1981. Biometry - The principals and practices of statistics in biological research, Second edition, W.H. Freemen and Company, New York, 859 p.

Thieme M.L., Abell R., Stiassny M.L.J., Skelton P., Lehner B., Teugels G.G., Dinerstein E., Kamdem Toham A., Burgess N. and Olson D. (eds.), 2005. Freshwater ecoregions of Africa and Madagascar: a conservation assessment, Island Press, Washington, DC, 431 p.

Traoré K.L., 1989. Caractéristiques physico-chimiques du Lac de Buyo. Rapport de Recherche, Institut d'Écologie Tropicale (IET), Côte d'Ivoire.

Traoré K., 1996. État des connaissances sur les pêcheries continentales ivoiriennes. Rapport de consultation, Projet FAO TCP/IVC/4553, IDESSA, Bouaké, Côte d'Ivoire.

Vilella F.S., Becker F.G. and Hartz S.M., 2002. Diet of Astyanax species (Teleostei, Characidae) in an Atlantic Forest River in Southern Brazil. Braz. Arch. Biol. Technol., 45, 2, 223-232.

Yao S.S., 2006. Contribution à l'étude de la diversité biologique et de l'écologie alimentaire de l'ichtyofaune d'un hydrosystème ouest africain : cas du bassin de la Comoé (Côte d'Ivoire). Thèse de Doctorat, Université de Cocody-Abidjan, Côte d'Ivoire, 280 p. 